\title{
Nutrient dynamics in a coastal lagoon (Ria Formosa, Portugal): The importance of lagoon-sea water exchanges on the biological productivity
}

\section{Dinámica de nutrientes en una laguna costera (Ría Formosa, Portugal): La importancia del intercambio de agua laguna-mar en la productividad biológica}

\author{
Manuela Falcão \\ Carlos Vale* \\ IPIMAR - Instituto de Investigação das Pescas e do Mar \\ Ave. Brasilia 1400, Lisboa, Portugal \\ *E-mail: cvale@ipimar.pt \\ Recibido en octubre de 2000; aceptado en septiembre de 2002
}

\begin{abstract}
Silicates, nitrates, phosphates, chlorophyll $a$ and primary productivity were monitored at low and high tide between September 1985 and September 1986, at four stations in Ria Formosa, a meso-tidal coastal lagoon located in the south of Portugal. The water sampling and the in situ observations were done alternatively in neap and spring tide. While silicates at low tide exceeded values at high tide thorughout the year and a weak seasonal trend was discerned, nitrates and phosphates exhibited a clear-cut seasonal variation at high spring tide. Pronounced maxima in the period of low temperatures (early spring), $7 \mu \mathrm{M}$ of nitrates and $3 \mu \mathrm{M}$ of phosphates, indicate their import from the adjacent coastal zone. Lower values at low tide and chlorophyll $a$ increases (up to $2 \mu \mathrm{g} \mathrm{g}^{-1}$ ) point to a rapid biological consumption of the imported nutrients. Differences of temperature between coastal waters and those of the lagoon in early spring account for the more efficient consumption by the primary producers of the lagoon. The primary productivity varied from $2 \mathrm{mg} \mathrm{C} \mathrm{m}^{-3} \mathrm{~h}^{-1}$ (winter) to $30 \mathrm{mg} \mathrm{C} \mathrm{m}^{-3} \mathrm{~h}^{-1}$ (summer), reflecting the intensive ${ }^{14} \mathrm{C}$ incorporation during the warmer period. High rates of nitrates and phosphates consumption could be observed during spring, when their concentrations decreased $50 \%$ within a narrow period of 6 hours from high to low tide.
\end{abstract}

Key words: Coastal lagoon, nutrients, chlorophyll, primary productivity, lagoon-sea exchanges.

\section{Resumen}

Se monitorearon silicatos, nitratos, fosfatos, clorofila $a$ y productividad primaria en mareas altas y bajas entre septiembre de 1985 y septiembre de 1986, en cuatro estaciones en la Ría Formosa, una laguna costera meso-mareal localizada en el sur de Portugal. Las muestras de agua y las observaciones in situ se realizaron en mareas muertas y vivas, de forma alternada. Mientras que durante la marea baja los silicatos excedieron los valores obtenidos en marea alta durante todo el año, estableciéndose una débil tendencia estacional, los nitratos y fosfatos mostraron una notoria variación estacional durante la pleamar de las mareas vivas. Los máximos pronunciados en el periodo de bajas temperaturas (inicios de primavera), de $7 \mu \mathrm{M}$ para nitratos y $3 \mu \mathrm{M}$ para fosfatos, indican su advección desde la zona costera contigua. Los valores menores durante la marea baja y el incremento en la clorofila $a$ (hasta $2 \mathrm{mg} \mathrm{g}^{-1}$ ), señalan un rápido consumo biológico de los nutrientes importados. Las diferencias de temperatura entre las aguas costeras, y las de la laguna al inicio de la primavera, promueven un consumo más eficiente entre los productores primarios de la laguna. La productividad primaria varió de $2 \mathrm{mg} \mathrm{C} \mathrm{m}^{-3} \mathrm{~h}^{-1}$ (invierno) a $30 \mathrm{mg} \mathrm{C} \mathrm{m}^{-3} \mathrm{~h}^{-1}$ (verano), reflejando una intensa incorporación de ${ }^{14} \mathrm{C}$ durante los periodos cálidos. Se pudo observar una elevada tasa de consumo de nitratos y fosfatos durante la primavera, cuando las concentraciones disminuyeron en un 50\% dentro de un corto período de 6 horas entre pleamar y bajamar.

Palabras clave: Laguna costera, nutrientes, clorofila, productividad primaria, intercambios laguna-mar.

\section{Introduction}

Tidally dominated coastal lagoons are complex and dynamic ecosystems whose physical, chemical and biological properties show a sharp distributional gradient and short-time to seasonal variability (Nogueira et al., 1997). The nutrient dynamics are driven by the feedback mechanisms between these ecosystems and the coastal waters (Nixon, 1980; Dame et al., 1986; Nixon et al., 1994). Most authors agree that part of

\section{Introducción}

Las lagunas costeras dominadas por la marea son ecosistemas complejos y dinámicos cuyas propiedades físicas, químicas y biológicas muestran un fuerte gradiente de distribución con variabilidades que van desde períodos cortos hasta estacionales (Nogueira et al., 1997). La dinámica de nutrientes es dominada por mecanismos de retroalimentación entre estos ecosistemas y las aguas costeras (Nixon, 1980; Dame et al., 
the lagoon biomass is exported offshore, the organic matter remineralized in the water column or in the sediments, and inorganic forms of nutrients are imported. Inside the lagoon the biogeochemical processes are extremely complex due to the interactions with the sediments and the benthic-pelagic competition of primary producers (Keizer et al., 1989; Fourqurean et al., 1993). In the case of nitrogen, sediments are a source as well as a major sink in the cycling of this element, regulating its concentration and, thus, the productivity of coastal marine systems (Lohse et al., 1993). In the case of phosphate, the great capacity of sediment and suspended sediments to release and/ or sequester phosphate, maintaining concentrations within a narrow range (Froelich, 1988; Vidal, 1994), may limit the availability of this nutrient for the phytoplankton. In fact, the short-term effects of suspended sediments lead to an effective competition between phytoplankton species and sediment particles for dissolved phosphate (Fourqurean et al., 1993; Vidal, 1994). In the open ocean, the processes involving the biogeochemistry of nitrogen and phosphorus are not so sharp as those occuring in shallow ecosystems (Fourqurean et al., 1993; Nixon et al., 1994). Some estuarine ecologists object to treating the coastal ocean as a source of nutrients for a lagoon or bay because the net long-term flux of nitrogen and phosphorus is virtually always outwards the estuary (Nixon et al., 1994). Thus, for coastal systems with permanent connection to the sea, ocean water may be the major source of inorganic nutrients required to support the productivity of an ecosystem. In this study the spatial, seasonal and tidal variability of nutrients, and the chlorophyll and primary productivity were assesed in a coastal lagoon connected to the sea. Our main concern was to understand the nutrient dynamics including the importance of water exchanges between the lagoon and the adjoining area, and the relationship of nutrient dynamics with the primary biological activity of the ecosystem.

\section{Sampling and methods}

Surface water was sampled twice a month at low and high tides, from September 1985 to September 1986 at four stations located in the main channels of Ria Formosa (fig. 1). Monthly samples were taken alternatively in neap tide (tidal amplitude $\sim 1 \mathrm{~m}$ ) and in spring tide (tidal amplitude $\sim 3 \mathrm{~m}$ ). Under this schedule water was collected throughout the year in four different situations: in neap tide periods (high tide and low tide), when the exchanges between the lagoon and the sea were minimal and, in spring tides (high tide and low tide) when they were maximal. Temperature was measured in situ with a probe. Other physical parameters were measured in the laboratory: salinity with a salinometer Beckman-RS7-C; pH with a Anna Instrument Cole-Parmer Inst. (combined electrode with silver/ silver chloride reference) within 2 hours after sampling; dissolved oxygen by the Winkler method (Grasshoff, 1976). Silicates, nitrates and phosphates were analysed with a Chemlab autoanalyser using the Technicon methodology. For the estimation of the primary productivity, vials were filled up
1986; Nixon et al., 1994). La mayoría de los autores concuerda en que parte de la biomasa de la laguna es exportada hacia el océano; en que la materia orgánica es remineralizada en la columna de agua o en los sedimentos; y en que se importan formas inorgánicas de nutrientes. Dentro de la laguna, los procesos biogeoquímicos son extremadamente complejos debido a las interacciones con los sedimentos y la competencia bénticapelágica de los productores primarios (Keizer et al., 1989; Fourqurean et al., 1993). En el caso del reciclamiento del nitrógeno, los sedimentos representan una fuente a la vez que su mayor sumidero, regulando así su concentración y, por tanto, la productividad de los sistemas marinos costeros (Lohse et al., 1993). En el caso del fosfato, la gran capacidad de los sedimentos y los sedimentos suspendidos para liberar o secuestrar fosfato, mantiene las concentraciones dentro de un rango estrecho (Froelich, 1988; Vidal, 1994), pudiendo limitar la disponibilidad de este nutriente para el fitoplancton. De hecho, los efectos de corto plazo de los sedimentos en suspensión conducen a una competencia efectiva por el fosfato disuelto entre las especies de fitoplancton y las partículas de sedimento (Fourqurean et al., 1993; Vidal, 1994). En el océano abierto, los procesos involucrados en la biogeoquímica del nitrógeno y del fósforo no son tan marcados como los que ocurren en ecosistemas someros (Fourqurean et al., 1993; Nixon et al., 1994). Algunos ecólogos de estuarios objetan el tratar al océano costero como una fuente de nutrientes para una laguna o bahía, dado que el flujo neto de nitrógeno o fósforo a largo plazo es virtualmente siempre hacia afuera del estuario (Nixon et al., 1994). Es por ello que, para sistemas costeros con conexión permanente con el océano, el agua de mar puede ser la principal fuente de los nutrientes inorgánicos requeridos para sostener la productividad del ecosistema. En el presente estudio se evaluaron la variabilidad espacial, estacional y mareal de los nutrientes, la clorofila y la productividad primaria en una laguna costera conectada al océano. Nuestro principal objetivo era el entender la dinámica de los nutrientes incluyendo la importancia del intercambio de agua entre la laguna y el área adyacente, así como la relación de la dinámica de nutrientes con la actividad biológica primaria de un ecosistema.

\section{Muestreo y métodos}

De septiembre de 1985 a septiembre de 1986, dos veces al mes se muestreó agua superficial en mareas baja y alta en cuatro estaciones localizadas en los canales principales de la Ría Formosa (fig. 1). Las muestras mensuales se tomaron alternando la marea muerta (amplitud mareal $\sim 1 \mathrm{~m}$ ) y marea viva (amplitud mareal $\sim 3 \mathrm{~m}$ ). Bajo este esquema, el agua fue colectada a lo largo del año en cuatro situaciones distintas: en periodos de marea muerta (pleamar y bajamar), cuando los intercambios entre la laguna y el mar eran mínimos, y en marea viva (pleamar y bajamar) cuando estos intercambios eran los mayores. La temperatura se midió in situ con una sonda y los demás parámetros físicos fueron medidos en el laboratorio: la salinidad con un salinómetro Beckman-RS7-C; el pH con un 


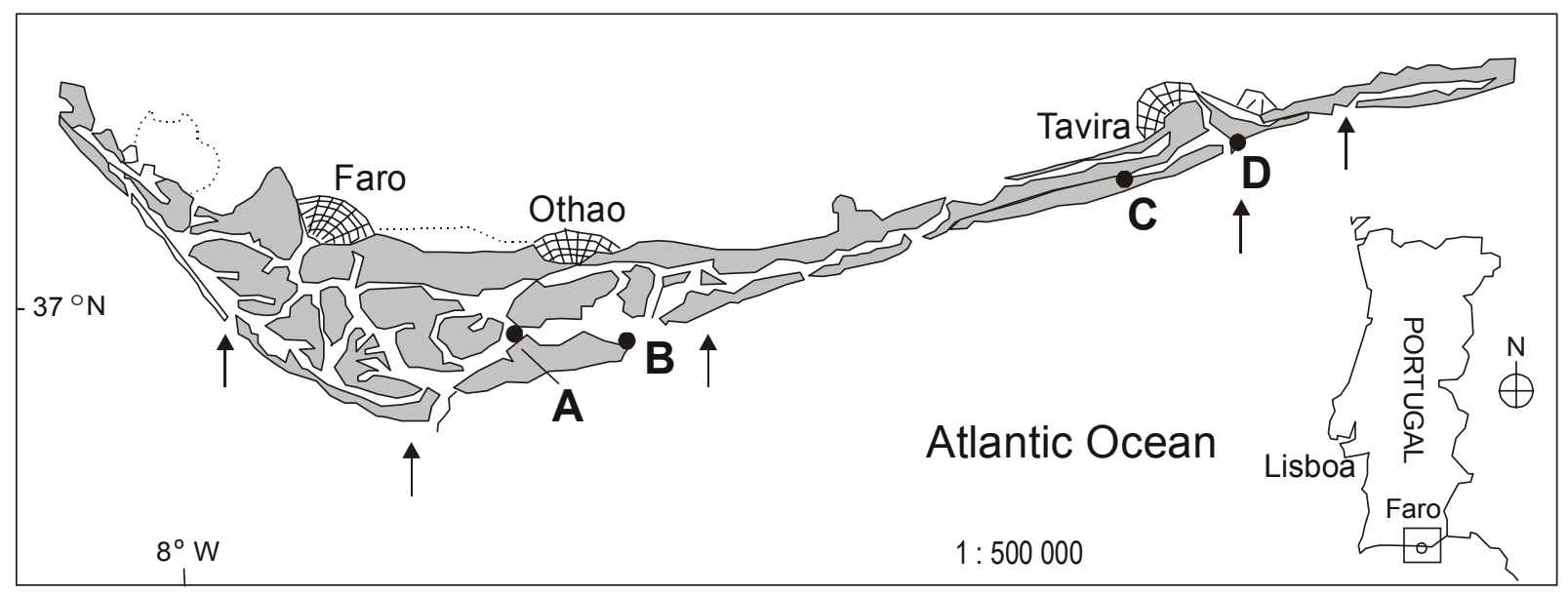

Figure 1. Ria Formosa and sampling stations $A, B, C$ and $D$.

Figura 1. Ría Formosa y estaciones de muestreo A, B, C y D.

with lagoon water, injected with ${ }^{14} \mathrm{C}$ and incubated in situ for 4 hours between 10:00 $\mathrm{h}$ and 14:00 h, and the carbon assimilation was determined by a scintillation counter LSC NE 6500 (FAO, 1975). Pigments and phaeopigments were determined with a Perkin-Elmer fluorometer according to the methodology described by Strickland and Parsons (1968). The detection limits of the determinations were: $0.1 \mu \mathrm{M}$ for silicate, $0.05 \mu \mathrm{M}$ for nitrate and nitrite, $0.1 \mu \mathrm{M}$ for phosphate, and $0.01 \mu \mathrm{g} \mathrm{L}^{-1}$ for pigments and phaeopigments.

\section{Results and discussion}

Observations of the water quality at low- and high-tide during tidal periods of contrasting amplitudes allow to assess the importance of exchanges between the lagoon and the adjoining area. The conditions at those periods may be particularly different in Ria Formosa, since the water volume exchanged in spring tides may be as much as $70 \%$ of the lagoon's total volume (Sprung, 1994). In order to discern better the seasonal variations of the exchanges, the results in neap and spring tides are presented in different plots (figs. 2-5).

Temperature, dissolved oxygen, $\mathrm{pH}$ and salinity

Water temperature in the four stations exhibited a seasonal fluctuation with a minimum in winter and a maximum in summer, and differences between low and high tide were minor (fig. 2). However, at spring tides the temperature remained low from February until April, while at neap tides an increase was observed in March. These differences indicate that warming up of coastal waters was delayed with respect to the lagoon water. Concentrations of dissolved oxygen were close to the saturation values and, at neap tides, the seasonal variation was almost reciprocal to that of the mean temperature. The maximum of $\mathrm{O}_{2}$ was found approximately a month after the
Anna Instrument - Cole-Parmer Inst. (electrodo combinado con una referencia de plata/cloruro de plata), dentro de las 2 horas posteriores al muestreo, y el oxígeno disuelto por el método de Winkler (Grasshoff, 1976). El silicato, el nitrato y el fosfato fueron medidos con un autoanalizador Chemlab utilizando la metodología Technicon. Para la estimación de la productividad primaria, se llenaron viales con agua de la laguna, se les inyectó ${ }^{14} \mathrm{C}$ y se incubaron in situ por 4 horas entre las 10:00 h y las 14:00 h. La asimilación de carbono se determinó por un contador de centelleo LSC NE 6500 (FAO, 1975). Los pigmentos y los feopigmentos fueron determinados con un fluorómetro Perkin-Elmer de acuerdo a la metodología descrita en Strickland y Parsons (1968). Los límites de detección de las determinaciones fueron: $0.1 \mu \mathrm{M}$ para silicato, $0.05 \mu \mathrm{M}$ para nitrato y nitrito, $0.1 \mu \mathrm{M}$ para fosfato y $0.01 \mu \mathrm{g} \mathrm{L}^{-1}$ para pigmentos y feopigmentos.

\section{Resultados y discusión}

Las observaciones de la calidad de agua en bajamar y pleamar durante periodos de marea con amplitudes contrastantes permiten evaluar la importancia de los intercambios entre la laguna y la zona contigua. Las condiciones durante esos periodos pueden ser particularmente diferentes en la Ría Formosa, ya que el volumen de agua intercambiado durante mareas vivas puede alcanzar el $70 \%$ del volumen total de la laguna (Sprung, 1994). Con el propósito de comprender mejor las variaciones estacionales de estos intercambios, los resultados para mareas muertas y vivas se presentan en gráficas distintas (figs. 2-5).

Temperatura, oxígeno disuelto, $\mathrm{pH}$ y salinidad

La temperatura del agua en las cuatro estaciones mostró una variación estacional con un mínimo en el invierno y un máximo en el verano, mientras que las diferencias entre la 
minimum mean temperature (fig. 2), which indicates that $\mathrm{O}_{2}$ concentration in early spring is substantially influenced by photosynthesis. This effect was not observed at spring tides presumably due to the large water volume exchanged with the sea. Differences among the stations were higher at low neap tide reflecting local processes. Values of NBS $\mathrm{pH}$ varied from 8.0 to 8.6 at neap tides, and fluctuated around $8.2($ s.d. $=0.13$ ) at spring tides due to mixing with incoming seawater. The higher values obtained at neap tide are probably influenced by photosynthesis. Because freshwater inputs are negligible and runoff episodes were absent during the annual study period (Falcão, 1997), the salinity was relatively constant (36.5) at the four stations during the annual survey. Differences in salinity between low and high tides were minor.

\section{Silicate}

Mean concentrations of silicates varied between 0.5 and $7 \mu \mathrm{M}$. Although higher values can be discerned at winter neap tides, their main characteristic relies in the fact that concentrations at low tide exceeded those recorded at high tide (fig. 3). The differences were found both at neap and spring tides. Moreover, values measured at high tide were relatively uniform, while differences among stations were found at spring tides. These results indicate that silicates are regenerated in the sediments and diffused out to the water column. With the flood there is a dilution effect and a silicate export to the coastal zone at the tidal rhythm. The importance of the bottom on the distribution of silicate has been observed in previous studies, particularly due to the clam cultures carried out in the marea baja y alta fueron menores (fig. 2). Sin embargo, durante las mareas vivas la temperatura permaneció baja de febrero a abril, mientras que en mareas muertas fue posible observar un incremento en marzo. Estas diferencias indican que el calentamiento en las aguas costeras se retrasó con respecto al agua de la laguna. Las concentraciones de oxígeno estuvieron cercanas a los valores de saturación y, en las mareas muertas, la variación estacional fue casi recíproca a la de la temperatura media. El máximo de $\mathrm{O}_{2}$ se encontró aproximadamente un mes después del mínimo de temperatura media (fig. 2), lo que indica que la concentración de $\mathrm{O}_{2}$ al inicio de la primavera está intensamente influenciada por la fotosíntesis. Este efecto no se observó en mareas vivas, posiblemente debido al gran volumen de agua intercambiado con el mar. Las diferencias entre las estaciones fueron mayores en bajamar de mareas muertas, reflejando procesos locales. Los valores de NBS $\mathrm{pH}$ variaron desde 8.0 hasta 8.6 en mareas muertas y fluctuaron alrededor de 8.2 (d.e. $=0.13)$ en mareas vivas, debido a la mezcla con el agua de mar entrante. Es muy posible que los valores más altos obtenidos en mareas muertas se encuentren influenciados por la fotosíntesis. Dado que los aportes de agua dulce son sumamente escasos y no se presentaron eventos de escorrentías durante el periodo anual de estudio (Falcão, 1997), la salinidad fue relativamente constante (36.5) en las cuatro estaciones durante el periodo anual de toma de datos. Las diferencias de salinidad entre mareas baja y alta fueron mínimas.

\section{Silicato}

Las concentraciones medias de silicatos variaron entre 0.5 y $7 \mu \mathrm{M}$. Aunque se encontraron valores más altos en las
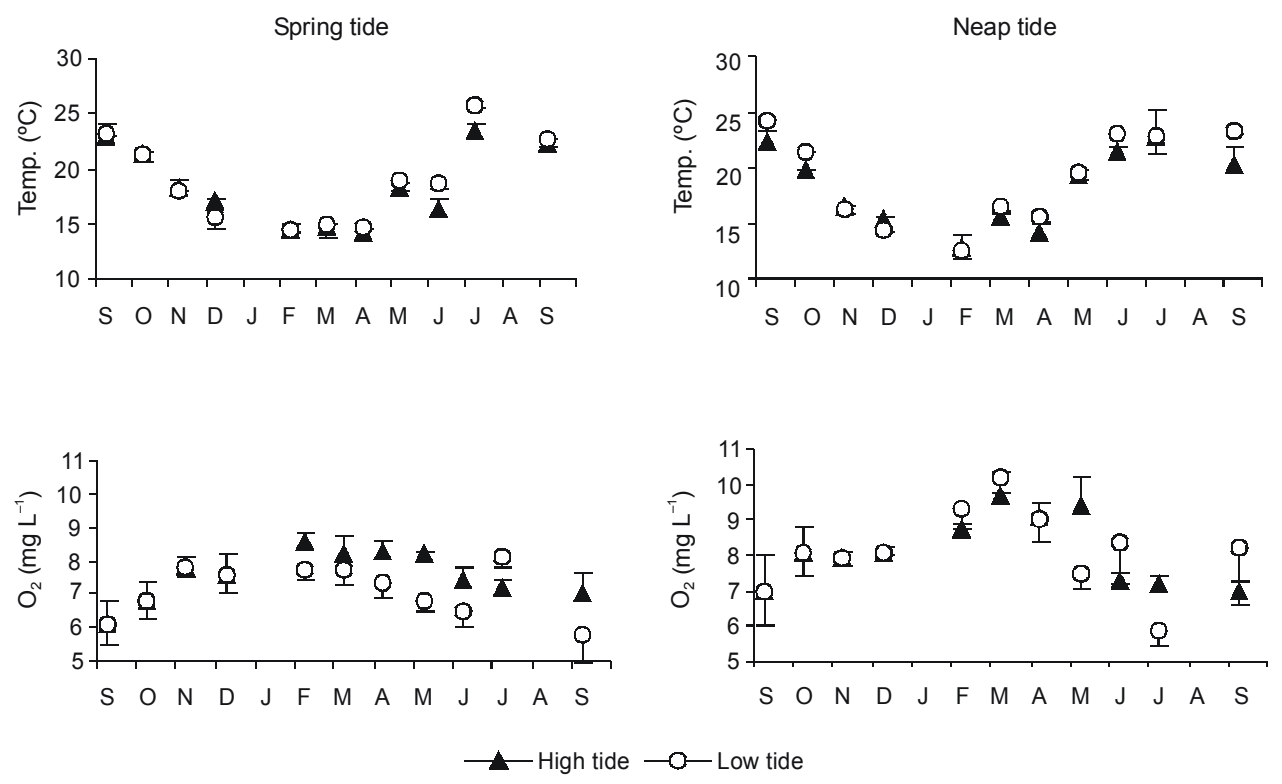

Figure 2. Annual variation of temperature $\left({ }^{\circ} \mathrm{C}\right)$ and dissolved oxygen $\left(\mathrm{mg} \mathrm{L}^{-1}\right)$ at spring tide (low tide -0 - and high tide $-\mathbf{\Delta}$-) and at neap tide (low tide -0- and high tide - $\Delta-$-). Mean values (stations A, B, C and D) and standard deviation.

Figura 2. Variación anual de la temperatura $\left({ }^{\circ} \mathrm{C}\right)$ y oxígeno disuelto $\left(\mathrm{mg} \mathrm{L}^{-1}\right)$ en marea viva (marea baja -0- y marea alta - $\left.\mathbf{\Delta}-\right)$ y

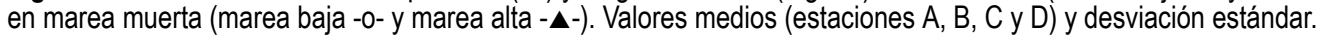


extensive inter-tidal flats of the lagoon (Falcão and Vale, 1990, 1998, 2000) and due to molecular diffusion (Ullman and Aller, 1989; Forja et al., 1994).

Nitrate and phosphate

An opposite pattern was found for nitrate and phosphate (fig. 3): both nutrients increased pronouncedly at spring tides with seawater incoming between February and April/May, when the water temperature was lower. At neap tide, values remained low and relatively constant along the annual period. Moreover, in the spring tides of that period, the standard deviation of the mean concentrations was considerably higher than in the rest of the year. This means that nitrate and phosphate concentrations were not uniformly distributed in the lagoon. The parallelism of the two distribution patterns, in addition to the fact that high concentrations were found at stations closer to the lagoon inlet, suggests that nitrates and phosphates are imported from the coastal zone in the period of low water temperature. This import is particularly important in spring tides, but the same trend tenuously observed at neap tides for phosphates indicates that, between February and April/May, mareas muertas de invierno, su característica principal reside en que las concentraciones en marea baja exceden a las registradas en marea alta (fig. 3). Las diferencias fueron encontradas tanto en mareas muertas como en mareas vivas. Mas aún, los valores medidos en pleamar fueron relativamente uniformes, mientras que las diferencias entre estaciones fueron encontradas en mareas vivas. Estos resultados indican que los silicatos son generados en los sedimentos y difundidos hacia la columna del agua. Con la inundación de la marea, hay un efecto de dilución y una exportación de silicato hacia la zona costera. La importancia del fondo en la distribución del silicato ha sido observada en estudios previos, en particular debida a los cultivos de ostras realizados en las extensas llanuras intermareales de la laguna (Falcão y Vale, 1990, 1998, 2000) así como a la difusión molecular (Ullman y Aller, 1989; Forja et al., 1994).

\section{Nitrato y fosfato}

Para el nitrato y el fosfato se encontró un patrón opuesto (fig. 3): entre febrero y abril-mayo, cuando la temperatura era
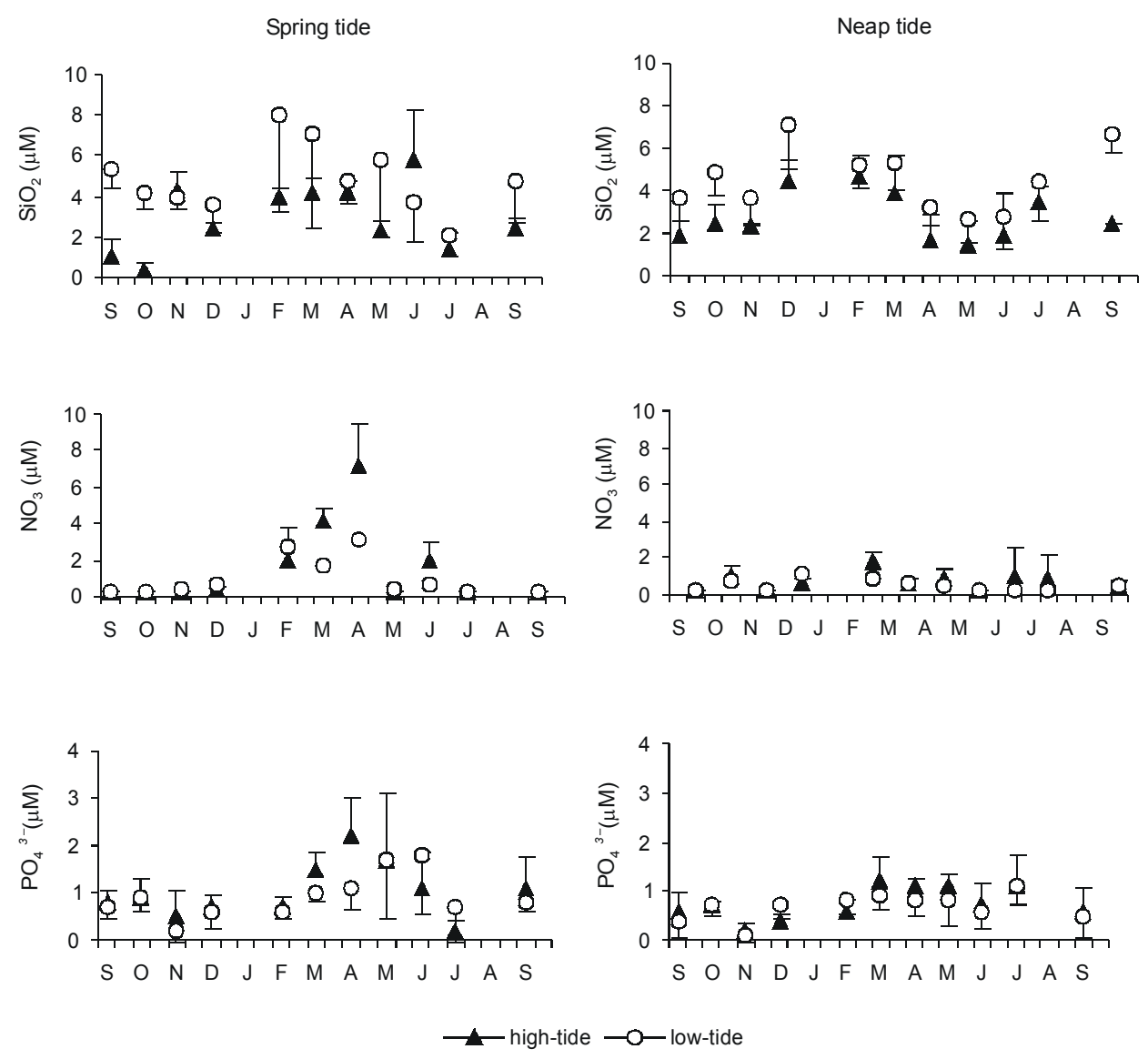

Figure 3. Annual variation of nitrate $(\mu \mathrm{M})$, phosphate $(\mu \mathrm{M})$ and silicate $(\mu \mathrm{M})$ at spring tide (low tide -0- and high tide - $\mathbf{\Delta}$-) and neap tide (low tide -0- and high tide - $\boldsymbol{\Delta}$-). Mean values (stations A, B, C and D) and standard deviation.

Figura 3. Variación anual del nitrato $(\mu \mathrm{M})$, fosfato $(\mu \mathrm{M})$ y silicato $(\mu \mathrm{M})$ en marea viva (marea baja -0- y marea alta - $\mathbf{\Delta}-$ ) y en marea muerta (marea baja -0- y marea alta - $\mathbf{\Delta}$-). Valores medios (estaciones A, B, C y D) y desviación estándar. 
consumption by the lagoon's primary producers does not balance the incoming seawater. Elevated concentrations at high tide indicate that nutrients in the coastal zone during winterspring are higher than those inside the lagoon, probably because the consumption by phytoplankton is more intense inside the lagoon. If we compare the low tide nutrient concentrations obtained at spring and at neap tide, one may infer that the higher values obtained at low spring tide are the remnant from those imported from the sea. This means that nutrients had no time to be completely consumed within the short period of 6 hours. These observations are in accordance with studies developed in other coastal systems that emphasize the importance of the import/export of nutrients for the ecology of the lagoon ecosystems (Nixon et al., 1994). The explanations invoked for the individual increase of nitrate and phosphate in water, such as rapid nitrification (Harrison et al., 1997) and release of phosphate from the sediment when dissolved oxygen decreases (Sundby et al., 1992), can not explain the distribution patterns observed in Ria Formosa. Besides the dilution effect, the decrease of nitrate and phosphate concentrations between high and low tides may also indicate a rapid consumption of the imported nutrients by the lagoon's primary producers.

\section{Chlorophyll $a$}

The time-course evolution of chlorophyll $a$ was in line with the nitrate, phosphate and $\mathrm{O}_{2}$ variations. Chlorophyll $a$ was low in winter and increased in early spring, defining a maximum from February to April (fig. 4). In this period the variability among stations was higher indicating a less uniform pigment distribution inside the lagoon. Many authors refer that the increase of pigments confirms the rapid biological assimilation of nitrates and phosphates by phytoplankton (Jordan et al., 1991). In fact, during early spring, the consumption of nitrates and phosphates observed from high tide to low tide correspond to the higher increase of chlorophyll $a$. This shows the importance of the nutrients imported from the coastal zone in this period for the production of phytoplankton inside the lagoon. The higher values of chlorophyll obtained at high tide in February and March, evidence an import of phytoplakton in this period while, after March, values at low tide surpass them. This means that the production of phytoplankton starts earlier in oceanic water than in the lagoon water but, after March, the lagoon exports phytoplankton.

\section{Primary productivity}

The seasonal variation of primary productivity measured during neap and spring tides is characterised by lower values in winter, a gradual increase in early spring, and high values in spring/summer (fig. 5). The period of higher primary production does not coincide with that of chlorophyll $a$, the higher carbon fixation occurring later. The carbon fixation rate was highest during summer, when nitrogen compounds were más baja, ambos nutrientes se incrementaron con el agua de mar entrante, en las mareas vivas. En mareas muertas los valores permanecieron bajos y relativamente constantes a lo largo del año. Además, en las mareas vivas de ese periodo, la desviación estándar de las concentraciones medias fue considerablemente mayor a la del resto del año. Esto significa que las concentraciones de nitrato y fosfato no estuvieron distribuidas de manera uniforme en la laguna. El paralelismo de los dos patrones de distribución, además del hecho de que las concentraciones elevadas se hayan encontrado en las estaciones cercanas a la boca de la laguna, sugiere que los nitratos y los fosfatos son importados de la zona costera en el periodo en que la temperatura del agua es menor. La importación es particularmente importante en las mareas vivas, aunque durante las mareas muertas también se observó ligeramente la misma tendencia para el fosfato. Esto indica que, entre febrero y abril-mayo, el consumo de los productores primarios de la laguna no contrarresta el agua de mar entrante. Las concentraciones elevadas en la pleamar indican que, durante invierno-primavera, los nutrientes son más abundantes en la zona costera que dentro de la laguna. Si se comparan las concentraciones obtenidas en la bajamar de mareas vivas con las de mareas muertas se puede inferir que los valores más altos obtenidos en la bajamar de la marea viva son aún remanentes de los importados desde el mar. Esto significa que no hubo tiempo para que los nutrientes fueran completamente consumidos dentro de un periodo corto de 6 horas. Estas observaciones concuerdan con estudios desarrollados en otros sistemas costeros que enfatizan la importancia de la importación/exportación de nutrientes para la ecología de los ecosistemas de lagunas costeras (Nixon et al., 1994). Las explicaciones formuladas para el incremento individual de nitrato y fosfato en el agua, tales como la rápida nitrificación (Harrison et al., 1997) y la liberación de fosfato desde el sedimento cuando el oxígeno disuelto disminuye (Sundby et al., 1992), no pueden explicar los patrones de distribución observados en la Ría Formosa. Además del efecto de dilución, la disminución de las concentraciones de nitrato y fosfato entre mareas altas y bajas también puede indicar un rápido consumo de los nutrientes importados por parte los productores primarios.

\section{Clorofila $a$}

La evolución de la clorofila $a$ siguió las variaciones del nitrato, el fosfato y el $\mathrm{O}_{2}$. La clorofila $a$ fue baja en invierno y se incrementó al inicio de la primavera, definiendo un máximo desde febrero hasta abril (fig. 4). En este periodo, la variabilidad entre estaciones fue más alta, indicando una uniformidad menor en la distribución del pigmento dentro de la laguna. Muchos autores señalan que el incremento de los pigmentos confirma una rápida asimilación biológica de nitratos y fosfatos por el fitoplancton (Jordan et al., 1991). De hecho, durante el inicio de la primavera, el consumo de nitratos y fosfatos observado desde la pleamar hasta la bajamar corresponde 


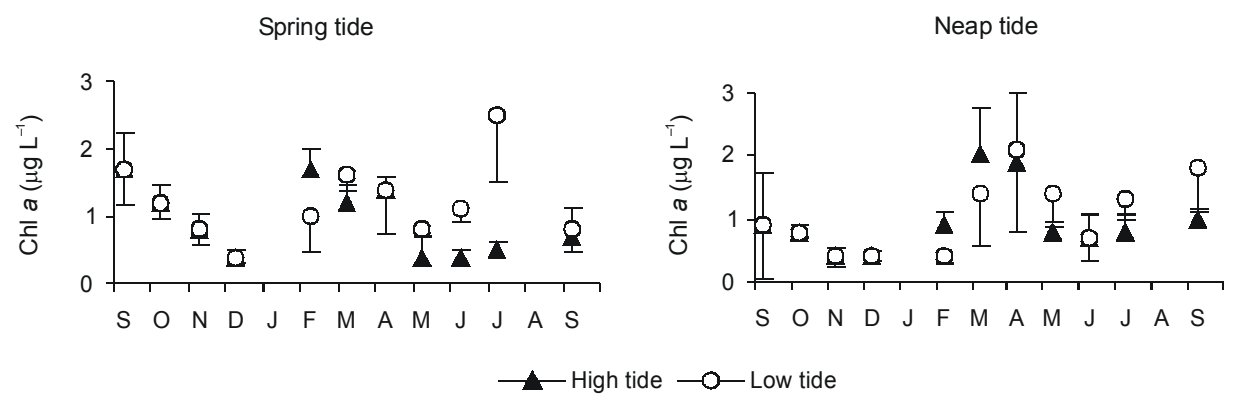

Figure 4. Annual variation of chlorophyll $a\left(\mu \mathrm{g} \mathrm{L}^{-1}\right)$ at spring tide (low tide -0- and high tide - $\left.\mathbf{\Delta}-\right)$ and neap tide (low tide -0- and high tide - $\mathbf{\Delta -}$-). Mean values (stations A, B, C and D) and standard deviation.

Figura 4. Variación anual de la clorofila $a\left(\mu \mathrm{L} \mathrm{L}^{-1}\right)$ en marea viva (marea baja -0- y marea alta - $\mathbf{\Delta -}$ ) y en marea muerta (marea baja -0- y marea alta - $\mathbf{\Delta}$-). Valores medios (estaciones A, B, C y D) y desviación estándar.

less abundant in the water (Falcão and Vale, 1998). This suggests that any nitrogen entering the system is being rapidly removed and/or that most of the carbon fixation is being supported by nitrogen that has been somehow rapidly remineralized within the system (Nixon, 1980). A significant contribution of ammonium may come from the intertidal sediments when they are flooded by the tide (Falcão and Vale, 1995). The lower values of primary productivity in this lagoon (2-9 $\mathrm{mg} \mathrm{C} \mathrm{m}{ }^{-3} \mathrm{~h}^{-1}$ in winter/autumn) are similar to those obtained in coastal waters, while higher values (20-30 mg C $\mathrm{m}^{-3} \mathrm{~h}^{-1}$ in spring/summer) are comparable to those of the most productive estuarine flats (Falcão, 1997). The photosynthetic efficiency, defined as the ratio between primary productivity and chlorophyll $a$, reaches the minimum during the winter period and follows a progressive increase from spring to summer (fig. 5) meaning that the maximum yield for the carbon fixation rate occurs during the summer.

\section{Conclusions}

This study reports nitrate and phosphate imports from the adjoining coastal area to the lagoon during the spring, and a permanent export of silicates out of it. These findings agree al mayor incremento de la clorofila $a$. Esto muestra la importancia de los nutrientes importados desde la zona costera en este periodo para la producción del fitoplancton dentro de la laguna. Los mayores valores de clorofila obtenidos en febrero y marzo en marea alta evidencian una importación de fitoplancton durante este periodo, mientras que, después de marzo, los valores en bajamar superan a los de pleamar. Esto significa que la producción del fitoplancton comienza antes en el agua oceánica que en la laguna pero, después de marzo, la laguna exporta fitoplancton.

\section{Productividad primaria}

La variación estacional de la productividad primaria medida durante las mareas muertas y vivas se caracteriza por tener valores más bajos en invierno, un incremento gradual a principios de la primavera y valores altos en primavera-verano (fig. 5). El periodo de mayor producción primaria no coincide con el de mayor cantidad de clorofila $a$, ya que la fijación intensa de carbono ocurre después. La tasa de fijación de carbono fue más alta durante el verano, cuando los componentes nitrogenados fueron menos abundantes en el agua (Falcão y Vale, 1998). Esto sugiere que cualquier especie de nitrógeno

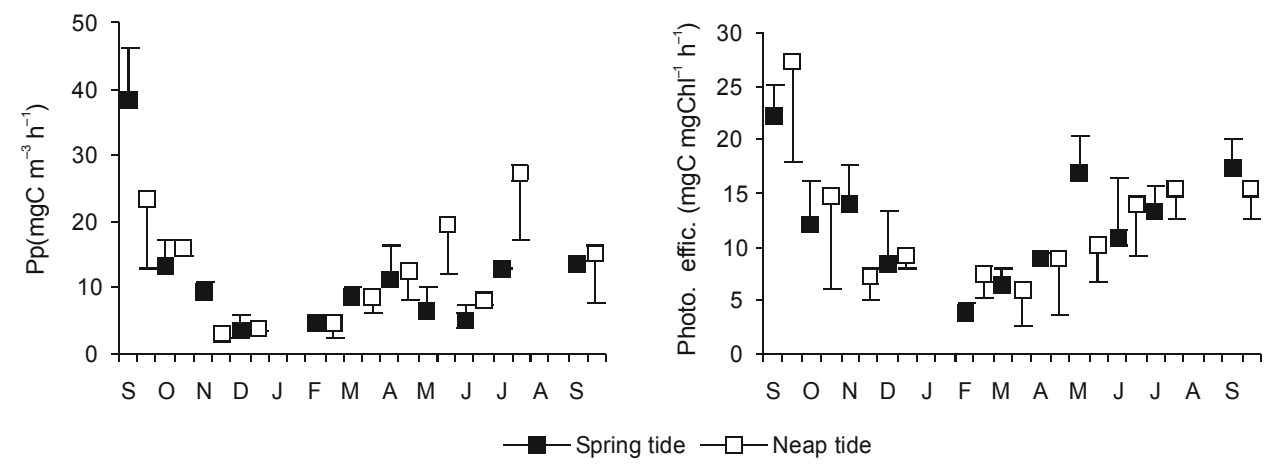

Figure 5. Annual variation of the primary productivity $\left(\mathrm{mgC} \mathrm{m}^{-3} \mathrm{~h}^{-1}\right)$ and photosynthetic efficiency $\left(\mathrm{mgC} \mathrm{mg} \mathrm{Ch}^{-1} \mathrm{~h}^{-1}\right)$ at spring tide - $\square$ - and neap tide - $\square$-. Mean values (stations A, B, C and D) and standard deviation.

Figura 5. Variación anual de la productividad primaria $\left(\mathrm{mgC} \mathrm{m}^{-3} \mathrm{~h}^{-1}\right)$ y eficiencia fotosintética $\left(\mathrm{mgC} \mathrm{mg} \mathrm{Chl}^{-1} \mathrm{~h}^{-1}\right)$ en marea viva - - y marea muerta - $\square$-. Valores medios (estaciones A, B, C y D) y desviación estándar. 
with others on the base of the nutrient concentrations obtained inside the lagoon and in the adjoining coastal area (Falcão, 1997). The nutrient exchanges calculated revealed an import of nitrates and phosphates during spring $(\sim 60 \%)$ and an export of silicates over the year. At spring tide, the fast consumption (from high tide to low tide) of the imported nitrates and phosphates may correspond to $50 \%$ of their total amount. Over there, the lowest levels of nitrates and phosphates observed when seawater incoming is negligible (neap tide) reinforce that the lagoon water is poor in nutrients because these are rapidly consumed. Part of the nutrients are consumed by the phytoplankton whose concentration increases during spring and, another part of them is presumably consumed by the micro-phytobenthos in the top-layer sediment as demonstrated by Sundbäck and Granéli (1988). Nutrients available for phytoplankton and phytobenthos consumption are not only those imported from coastal waters but also those released from the bottom. The influence of the bottom in the regeneration of nutrients that enrich the water column should not be negligible mainly concerning ammonium, phosphate and silicate (Lerat $e t$ al., 1990; Kristensen, 1993; Hopkinson, 1987; Forja et al., 1994). Studies developed in this lagoon demonstrated that inter-tidal areas are apparently capable of supplying most of the daily $\mathrm{N}$ and $\mathrm{P}$ requirements of phytoplankton in the overlying water (Falcão and Vale, 1998). Other authors demonstrate that rates of net nitrogen mineralization were relatively low during most of the year with a particularly active period from June to August, possibly due to an effect of the temperature on soil microbial activity (Cartaxana et al., 1999). However, the enrichment of the water column in nitrogen and phosphorus during summer was not observed in this work suggesting its immediate consumption. The sharp increase of primary productivity obtained during the summer might be translated into high rates of nutrient production and consumption. On the base of these findings and according to the classification of trophic degrees in marine systems (Wetzel, 1983), Ria Formosa may be considered oligomesotrophic in winter/autumn and hipertrophic in spring/summer. Our results confirm that nutrients imported from the coastal waters as well as those produced inside the lagoon, are enough to maintain an autotrophically dominated system in spite of inexpressive fresh water inputs.

\section{References}

Cartaxana, P., Caçador, J., Vale, C., Falcão, M. and Catarino, F. (1999). Seasonal variation of inorganic nitrogen and net mineralization in a salt marsh ecosystem. Mangroves and Salt Marshes, 3: 127-134.

Dame, R., T. Chrzanowski, K. Bildstein, B. Kjerive, H. McKellar, D.Nelson, J. Spurrier, S. Stancyk, H. Stevenson, J. Vernberg and Zingmark, R. (1986). The outwelling hypothesis and North Inlet, South Carolina. Mar. Ecol. Prog. Ser., 33: 217-229.

Falcão, M. (1997). Dinâmica dos nutrientes na Ria Formosa: interacção da laguna com as suas interfaces na reciclagem do que entra al sistema es removida rápidamente y/o que casi toda la fijación de carbono está sustentada por el nitrógeno que, de alguna manera, ha sido remineralizado rápidamente dentro del sistema (Nixon, 1980). Una contribución significativa de amonio puede provenir de los sedimentos intermareales cuando son inundados por efecto de la marea (Falcão y Vale, 1995). Los menores valores de productividad primaria en esta laguna (2-9 $\mathrm{mg} \mathrm{C} \mathrm{m}^{-3} \mathrm{~h}^{-1}$ en invierno/otoño) son similares a los obtenidos en aguas costeras, mientras que los valores más altos (20-30 $\mathrm{mg} \mathrm{C} \mathrm{m}^{-3} \mathrm{~h}^{-1}$ en primavera/verano) son comparables a los de las llanuras estuarinas más productivas (Falcão, 1997). La eficiencia fotosintética, definida como la relación entre la productividad primaria y la clorofila $a$, alcanza el mínimo durante el invierno y sigue un incremento progresivo desde la primavera hasta el verano (fig. 5), lo que significa que el máximo rendimiento de la tasa de fijación de carbono ocurre durante el verano.

\section{Conclusiones}

Este estudio reporta la importación de nitratos y fosfatos desde áreas costeras colindantes durante la primavera y la permanente exportación de silicatos. Estos descubrimientos concuerdan con otros en base a las concentraciones de nutrientes obtenidas dentro de la laguna y en el área costera adyacente (Falcão, 1997). Los intercambios de nutrientes calculados revelan una importación de nitratos y fosfatos durante la primavera $(\sim 60 \%)$ y una exportación de silicatos a lo largo del año. En mareas vivas, el rápido consumo de nitratos y fosfatos importados (de marea alta a marea baja) puede corresponder al 50\% del total importado. Allí, los niveles más bajos de nitratos y fosfatos observados cuando la entrada de agua es casi nula (marea muerta) refuerzan el hecho de que el agua de la laguna es pobre en nutrientes, dado que estos son rápidamente consumidos. Parte de los nutrientes son consumidos por el fitoplancton cuya concentración se incrementa durante la primavera, y otra parte es presumiblemente consumida por el microfitobentos de la capa superior del sedimento, como fue demostrado por Sundbäck y Granéli (1988). Los nutrientes disponibles para el consumo del fitoplancton y el fitobentos no sólo son los importados de las aguas costeras, sino también los liberados desde el fondo. La influencia del fondo en la regeneración de nutrientes que enriquecen la columna de agua no debe ser despreciada, en especial en relación al amonio, fosfato y silicato (Lerat et al., 1990; Kristensen, 1993; Hopkinson, 1987; Forja et al., 1994). Los estudios desarrollados en esta laguna demostraron que las areas intermareales aparentemente son capaces de abastecer casi todo el $\mathrm{N}$ y $\mathrm{P}$ requeridos por el fitoplancton en la capa de agua superior (Falcão y Vale, 1998). Otros autores demostraron que las tasas netas de mineralización de nitrógeno fueron relativamente bajas durante la mayor parte del año, con un periodo particularmente activo de junio a agosto, posiblemente debido a un efecto de la temperatura sobre la actividad microbiana del suelo (Cartaxana et al., 1999). Sin embargo, en este trabajo no se observó el 
azoto, fósforo e sílica. Tese de Doutoramento em Ciências do Mar, pela Universidade do Algarve. 223 pp.

Falcão, M. and Vale, C. (1990). Study of the Ria Formosa ecosystem: bentic nutrient remineralization and tidal variability of nutrients in the water. Hydrobiologia, 207: 137-146.

Falcão, M. and Vale, C. (1995). Tidal flushing of ammonium from inter-tidal sediments of Ria Formosa, Portugal. Neth. J. Aquat. Ecol., 29(3-4): 239-244.

Falcão, M. and Vale, C. (1998). Sediment-water exchanges of ammonium and phosphate in intertidal and subtidal areas of a mesotidal coastal lagoon (Ria Formosa). Hydrobiologia, 373/374: 193-201.

Falcão, M. and Vale, C. (2000). Efeito da ameijoa Ruditapes decussatus nas trocas de amónia junto à interface sedimento-água. Estudos de Biogeoquímica na Zona Costeira Ibérica. Publ. Univ. de Aveiro- IX Seminário Ibérico de Química Marinha: 125-130.

FAO. (1975). Manual of methods in aquatic environmental research. FAO Fish. Tech. 128 pp.

Forja, J. M., J. Blasco, J. and Gómez-Parra. (1994). Spatial and seasonal variation of in situ benthic fluxes in the Bay of Cadiz. (South-west Spain). Estuar. Coast. Shelf Sci., 39: 127-141.

Fourqurean, J. W., R. D. Jones and Zieman, J. C. (1993). Processes influencing water column nutrient characteristics and phosphorus limitation of phytoplankton biomass in Florida Bay, FL, USA: Interferences from spatial distributions. Estuar. Coast. Shelf Sci., 36: 295-314.

Froelich, P. N. (1988). Kinetic control of dissolved phosphate in natural rivers and estuaries: a primer on the phosphate buffer mechanism. Limnol. Oceanogr., 33: 649-668.

Grasshoff, K. (1976). Methods of Seawater Analysis. Verlag chemieNew York: 317 pp.

Harrison, P. J., Khan, N., Yin, K., Saleem, M., Bano, N., Nisa, M., Ahmed, S. I., Rizvi, N. and Azam, F. (1997). Nutrient and phytoplankton dynamics in two mangrove tidal creeks of the Indus River delta, Pakistan. Mar. Ecol. Prog. Ser., 43: 63-69.

Hopkinson, C., S. (1987). Nutrient regeneration in shallow-water sediments of the estuarine plume region of the nearshore Georgia Bight, U. S. A. Mar. Biol., 94: 127-142.

Jordan, T. E., D. L. Correll, J. Miklas and Weller, D. E. (1991). Nutrients and chlorophyll at the interface of a watershed and an estuary. Limnol. Oceanogr., 36(2): 251-267.

Keizer, P. D., B. T. Hargrave and Gordon, D. C. (1989). Sedimentwater exchange of dissolved nutrients at an intertidal site in the upper reaches of the Bay of Fundy. Estuaries, 12 (1): 1-12.

Kristensen, E. (1993). Seasonal variations in benthic community metabolism and nitrogen dynamics in a shallow, organic-poor Danish lagoon. Estuar. Coast. Shelf Sci., 36: 565-586.

Lerat, Y., Lasserre. P. and Corre, P. (1990). Seasonal changes in pore water concentrations of nutrients and their diffusive fluxes at the sediment-water interface. J. Exp. Mar. Biol. Ecol., 135: 135-160.

Lohse, L., Malschaert, J. F. P., Slomp, C. P., Helder, W and Van Raaphorst, W. (1993). Nitrogen cycling in North Sea sediments: enriquecimiento de la columna de agua en nitrógeno y fósforo durante el verano, lo que sugiere su consumo inmediato. El incremento tan marcado de la productividad primaria durante el verano se puede traducir en elevadas tasas de producción y consumo de nutrientes. Con base en lo anterior, y de acuerdo a la clasificación de grados tróficos en sistemas marinos (Wetzel, 1983), la Ría Formosa puede ser considerada como oligomesotrófica durante invierno/otoño e hipertrófica durante primavera/verano. Nuestros resultados confirman que los nutrientes importados de aguas costeras, así como los producidos dentro de la laguna, son suficientes para mantener un sistema predominantemente autotrófo, a pesar de los escasos aportes de agua dulce.

Traducido al español por Adrián R. López-González.

interaction of denitrification and nitrification in offshore and coastal areas. Mar. Ecol. Prog. Ser., 101: 283-296. Nixon, S. W. (1980). Between coastal marshes and coastal waters-a review of twenty years of speculation and research on the role of salt marshes in estuarine produtivity and water chemistry. In P. Hamilton and K. B. MacDonald (eds.), Estuarine and Wetland Processes. Plenum Publ. Corp., New York: 437-525.

Nixon, S. W., Granger, S. L., Taylor, D. I., Johnson, P. W. and Buckley, B. A. (1994). Subtidal volume fluxes, nutrient inputs and the brown tide - an alterate hypothesis. Estuar. Coast. Shelf Sci., 39: 303-312.

Nogueira, E., Pérez, F. F.and Ríos, A. F. (1997). Seasonal patterns and long-term trends in an estuarine upwelling ecosystem (Ría de Vigo, NW Spain). Estuar. Coast. Shelf Sci., 44: 285-300

Sprung, M. (1994). Macrobenthic sedendary production in the intertidal zone of the Ria Formosa - a lagoon in southern Portugal. Estuar. Coast. Shelf Sci., 38: 539-558.

Strikland, J. D. H. and Parson, T. R. (1968). A Pratical Handbook of Seawater Analysis. Fisheries Research Board of Canada. Ottawa. $311 \mathrm{pp}$.

Sundbäck, K. and Granéli, W. (1988). Influence of microphytobenthos on the nutrient flux between sediment and water: a laboratory study. Mar. Ecol. Prog. Ser., 43: 63-69.

Sundby, B., C. Gobeil, N. Siverberg and Mucci, A. (1992). The phosphorus cycle in coastal marine sediments. Limnol. Oceanogr., 37: 1129-1145.

Ullman, W. J. and Aller, R. C. (1989). Nutrient release rates from the sediments of Saginaw Bay, Lake Huron. Hydrobiologia, 171: 127-140.

Vidal, M. (1994). Phosphate dynamics tied to sediment disturbances in Alfacs Bay (NW Mediterranean). Mar. Ecol. Prog. Ser., 110: 211-221.

Wetzel, R. G. (1983). Limnology. Second ed. Saunders College Pub., Philadelphia, PA. 767 pp. 